\title{
CARING PERAWAT BERHUBUNGAN DENGAN KECEMASAN ORANGTUA YANG ANAKNYA HOSPITALISASI
}

\author{
Jek Amidos Pardede*, Marthalena Simamora \\ Program Studi Ners, Universitas Sari Mutiara Indonesia, Jln. Kapten Muslim No.79 Medan, Indonesia 20123 \\ *jekpardedemi@rocketmail.com (+6281361009005)
}

\begin{abstract}
ABSTRAK
Caring dalam keperawatan merupakan hal yang mendasar. Fenomena dilapangan adanya perawat tidak caring dalam memberikan asuhan keperawatan, dimana terlihat sebagian perawat masih ada yang kurang caring, terlihat ketika perawat memberikan tindakan keperawatan dan tidak menerapkan senyum, sapa, sentuh, sehingga anak tampak menangis setiap perawat melakukan tindakan dan menarik tangannya karena takut disuntik. Perawatan dirumah sakit bagi anak merupakan pengalaman yang tidak menyenangkan sehingga menimbulkan kecemasan bagi anak dan orangtua. Tujuan dari penelitian ini adalah untuk mengetahui caring perawat dengan kecemasan orangtua yang anaknya hospitalisasi di ruang rawat inap delima lantai IV Rumah Sakit Sari Mutiara Medan Tahun 2017. Desain penelitian ini adalah deskriptif korelasi dengan menggunakan pendekatan cross sectional. Populasi dalam penelitian ini yaitu orangtua yang mendampingi anak yang dirawat berjumlah 116 orang dan sampel penelitian ini berjumlah 54 orang dengan tehnik pengambilang sampel dengan purposive sampling. Pengumpulan data dilakukan dengan menggunakan kuesioner. Analisia data menggunakan uji statistik chi-square dengan nilai standar alpha a $<0,05$. Hasil penelitian ini didapatkan bahwa caring perawat manyoritas baik sebesar $51,9 \%$ dan kecemasan orangtua manyoritas cemas sedang sebesar $61.1 \%$ dengan pvalue $<0,03$ sehingga dapat disimpulkan caring perawat dengan kecemasan orangtua yang anaknya hospitalisasi di ruang rawat inap delima lantai IV Rumah Sakit Sari Mutiara Medan ada hubungan yang signifikan.
\end{abstract}

Kata kunci: caring perawat, hospitalisasi, kecemasan orangtua

\section{CARING NURSES RELATED TO PARENTAL ANXIETY THE CHILDREN OF HOSPITALIZATION}

\begin{abstract}
Caring in nursing is a fundamental thing. The phenomenon in the field of the presence of nurses are not caring in providing nursing care, which is seen some nurses are still less caring, seen when the nurse gave nursing action and did not apply a smile, Sapa, touch, so the child appears to cry every nurse took action and pulled her hand for fear of being injected. Hospital care for children is an unpleasant experience that raises anxiety for children and parents. The purpose of the study is to know the caring nurses with the anxiety of the parents whose children are hospitalized in the room of Pomegranate Sari Mutiara Hospital in Medan year 2017. Design research is a descriptive correlation using the cross sectional approach. The population in this study is the parents who accompany the child who is treated for 116 people and the sample of this research amounted to 54 people with the technique of the sampling. Data collection is performed using questionnaires. Data analysis using the Chi-square statistical test with a standard value of alpha $a<0.05$. The results of this study was obtained that the caring nurse good manyoritas at $51.9 \%$ and the anxiety of elderly manyoritas anxious at $61.1 \%$ with a pvalue of $<0.03$ so that the care can be concluded nurse with the anxiety of parents whose children are hospitalized in the inpatient room of hospital Sari Mutiara Medan There is a significant relationship
\end{abstract}

Keywords: caring nurses, hospitalization, parental anxiety 


\section{PENDAHULUAN}

Hospitalisasi merupakan suatau keadaan krisis yang terjadi pada anak, yang terjadi ketika anak sakit dirawat di rumah sakit. Hospitalisasi pada anak merupakan suatu keadaan krisis pada anak. Keadaan ini terjadi karena anak berusaha untuk beradaptasi dengan lingkungan asing dan baru yaitu rumah sakit, sehingga kondisi tersebut menjadi faktor stressor baik terhadap anak maupun orangtua dan keluarga (Wong, 2002 dalam Mulyatiningsih 2014). Perasaan yang sering muncul pada anak, saat di hospitalisasi adalah rasa marah, rasa sedih, rasa takut, dan rasa bersalah (Apriliawati, 2011).

Hospitalisasi adalah suatu proses yang mengharuskan anak tinggal di rumah sakit menjalani terapi dan perawatan sampai sembuh yang akhirnya kembali pulang ke rumah (Suryanti, 2013). Selama proses tersebut, anak dapat mengalami berbagai kejadian berupa pengalaman yang sangat traumatik dan penuh dengan stres. Hasil penelitian De Breving et al, (2015) menunjukkan bahwa lingkungan rumah sakit yang dapat menimbulkan trauma bagi anak adalah lingkungan fisik rumah sakit, tenaga kesehatan baik dari sikap maupun pakaian putih, alat-alat yang digunakan, dan lingkungan sosial antara sesama pasien. Pasien anak banyak bereaksi dengan menangis dan memberontak serta meminta perlindungan kepada orangtua atau orang terdekatnya.

Hospitalisasi juga memberikan dampak negatif seperti suatu perpisahan dan penyesuaian dengan lingkungan yang asing baginya. penyesuaian dengan banyak orang mengurusinya, kerap kali berhubungan dan bergaul dengan anak anak yang sakit serta pengalaman mengikuti terapi yang menyakitkan (Lumiu, 2013). Hospitalisasi sering kali menjadi krisis pertama yang harus dihadapi anak. Anak- anak, terutama selama tahun-tahun awal, sangat rentan terhadap krisis penyakit dan hospitalisasi karena stress akibat perubahan dari keadaan sehat biasa dan rutinitas lingkungan

(Akhriansyah, 2018)

Anak yang pernah mengalami perawatan di rumah sakit tentu akan menunjukkan reaksi berbeda bila dibandingkan dengan anak yang belum pernah. Hal ini sesuai dengan penelitian Gaghiwa, (2013). Reaksi anak yang sudah perna mengalami perawatan dirumah sakit merasa familiar dengan lingkungan rumah sakit, tidak merasa cemas dan takut, sedangkan anak yang belum perna menjalani perawatan dirumah sakit akan menimbulkan reaksi seperti takut, menanggis dan menolak dalam pemberian tindakan. Anak yang sakit dapat menimbulkan suatu stres bagi anak itu sendiri maupun keluarga (Setiawan et al, 2014).

Di Amerika Serikat, diperkirakan lebih dari 5 juta anak menjalani hospitalisasi karena prosedur pembedahan dan lebih dari $50 \%$ dari jumlah tersebut, anak mengalami kecemasan dan stres (Apriliawati, 2011). Di Indonesia diperkirakan 35 per 1000 anak menjalani hospitalisasi (Purwandari, 2009). Prevalensi (angka kesakitan) gangguan kecemasan yang terjadi pada anak saat di rumah sakit berkisar pada angka 60-80\% dari populasi umum (Sarifah, 2016).

Hospitalisasi pada anak dapat menyebabkan kecemasan orangtua terkait dengan diagnosa penyakit anak. Kecemasan orangtua dapat dipengaruhi oleh beberapa hal, salah satunya yaitu lama hari rawat anak. Lama hari rawat dapat diukur dan dinilai, lama hari rawat yang memanjang disebabkan oleh kondisi medis pasien atau adanya infeksi nosokomial (Wartawan, 2012).

Dampak negatif dari efek hospitalisasi sangat berpengaruh terhadap upaya perawatan dan pengobatan yang sedang dijalani pada anak. Reaksi yang dimunculkan pada anak akan berbeda antara satu dengan lainnya, Penelitian Kumayah, (2011). Lama hari rawat dapat menyebabkan kecemasan pada orangtua karena memikirkan pengobatan, keadaan 
dirumah sakit dan biaya dalam perawatan. Hal ini akan nampak saat orangtua mengurangi peran dalam mendampinggi anaknya menjalani hospitalisasi.

Orangtua merasakan kecemasan yang tinggi terhadap tindakan anestesi yang akan dilakukan terhadap anak mereka, meskipun begitu orangtua mampu mengatasinya setelah mendapatkan informasi yang lebih jelas dari dokter dan perawat. Anak yang akan menjalani pembedahan $40 \%$ orangtua dengan elektif melaporkan jika kecemasan berkurang setelah mendapat informasi yang jelas sebelum operasi. Sehingga perlulah perawat memberikan yang terbaik buat anak dan orangtuanya dengan memberikan sikap caring juga sudah membantu anak dan orangtuanya.

Perilaku caring perawat pelaksana di rumah sakit dapat dipengaruhi oleh budaya organisasi. Kreitner \& Kinicki (2010) menekankan bahwa budaya organisasi yang kuat menciptakan kesamaan tujuan, motivasi karyawan, dan struktur pengendalian untuk membentuk perilaku yang dibutuhkan dalam meningkatkan prestasi organisasi yang berdampak pada kinerja anggota organisasi. Bukti empirik mengenai faktor yang mempengaruhi perilaku caring perawat sebagai wujud kinerja.

Penelitian Prabowo et al, (2014) menunjukkan bahwa perawat yang memiliki tingkat kognitif baik tentang caring, maka akan menunjukkan kemampuan perilaku caring yang baik pula. Sejalan dengan penelitian Wicaksono (2012) bahwa keperawatan yang baik dan sesuai harapan dalam sebuah rumah sakit meningkatkan mutu asuhan keperawatan dengan penerapan kiat caring perawat dan melakukan supervisi secara berkala sesuai standar untuk mengevaluasi kinerja perawat. Model asuhan keperawatan profesional yang lebih efisien dan efektif sehingga mampu memberikan kepuasan baik dari pihak pasien, keluarga, perawat maupun tim kesehatan lain. Begitu juga dengan penelitian Meliana (2013) mendapatkan hasil bahwa caring perawat terkait hospitalisasi anak dapat menurunkan kecemasan anak juga orangtuanya.

\section{METODE}

Desain penelitian ini adalah deskriptif korelasi dengan mengunakan pendekatan cross sectional. Populasi dalam penelitian sebanyak 116 dengan rata rata perbulan orangtua yang anaknya hospitalisasi. Sampel penelitian ini sebanyak 54 orang dengan menggunakan tehnik purposive sampling dengan memenuhi kriteria yang ditentukan dengan memperhatikan kriteria inklusi. Kriteria inklusinya adalah orangtua kandung anak yang di hospitalisasi, orangtua yang pertama kali membawa anaknya ke rumah sakit, orangtua sebagai pendamping utama selama anak dirawat dan orangtua yang selalu ada bersama anak. Alat pengumpulan data menggunakan kuesioner caring perawat sebanyak 41 pernyataan dengan cronbach alpha yaitu 0,917 dan kuesioner kecemasan orangtua sebanyak 45 pernyataan dengan cronbach alpha yaitu 0,919. Uji stastistik yang dilakukan dengan chi-square test.

\section{HASIL}

Hasil penelitian disajikan sebagai berikut.

Tabel 2.

Caring Perawat $(\mathrm{n}=54)$

\begin{tabular}{lcc}
\hline Caring perawat & f & $\%$ \\
\hline Baik & 28 & 51.9 \\
Buruk & 26 & 48.1 \\
\hline
\end{tabular}

Tabel 3 dapat dilihat caring perawat mayoritas baik. 
Tabel 1.

Karakteristik responden $(n=54)$

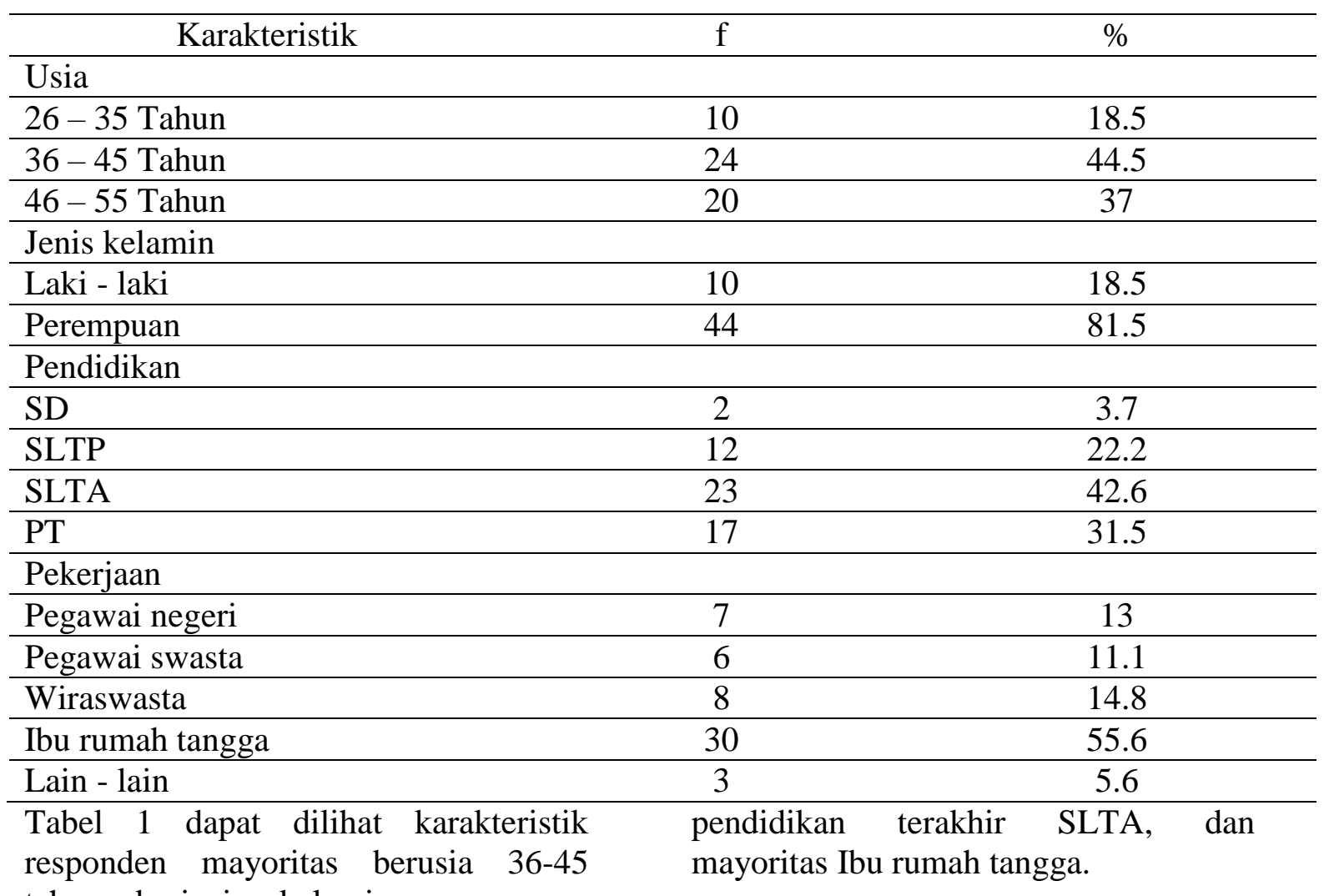

Tabel 3.

Tingkat kecemasan orangtua $(n=54)$

\begin{tabular}{lcc}
\hline Kecemasan orangtua & $\mathrm{f}$ & $\%$ \\
\hline Ringan & 14 & 25.9 \\
Sedang & 33 & 61.1 \\
Berat & 7 & 13 \\
\hline
\end{tabular}

Tabel 3 dapat dilihat kecemasan orangtua yang anaknya hospitalisasi
Tabel 4.

mayoritas pada tingkat kecemasan sedang.

Hubungan caring perawat dengan kecemasan orangtua yang anaknya hospitalisasi

\begin{tabular}{|c|c|c|c|c|c|c|c|c|}
\hline \multirow{3}{*}{$\begin{array}{l}\text { Caring } \\
\text { Perawat }\end{array}$} & \multicolumn{7}{|c|}{ Kecemasan Orangtua } & \\
\hline & \multicolumn{2}{|c|}{ Ringan } & \multicolumn{2}{|c|}{ Sedang } & \multicolumn{2}{|c|}{ Berat } & \multirow{2}{*}{$\frac{\text { Total }}{\mathrm{f}}$} & \\
\hline & $\mathrm{f}$ & $\%$ & $\mathrm{f}$ & $\%$ & $\mathrm{f}$ & $\%$ & & \\
\hline Baik & 3 & 10.7 & 22 & 78.6 & 3 & 10.7 & 28 & 0,034 \\
\hline Buruk & 10 & 38.5 & 12 & 46.2 & 14 & 15.4 & 26 & 48,1 \\
\hline \multicolumn{5}{|c|}{$\begin{array}{l}\text { Tabel } 4 \text { dapat dilihat caring perawat } \\
\text { buruk sebanyak } 48,1 \% \text { dengan orangtua } \\
\text { yang mengalami kecemasan ringan } \\
\text { sebanyak } 38,5 \% \text {, orangtua yang } \\
\text { mengalami kecemasan sedang sebanyak } \\
46,2 \% \text {, dan orangtua yang mengalami }\end{array}$} & \multicolumn{4}{|c|}{$\begin{array}{l}\text { kecemasan berat sebanyak } 15,4 \% \text {. } \\
\text { Responden yang menyatakan caring } \\
\text { perawat baik sebanyak } 51,4 \% \text { dengan } \\
\text { orangtua yang mengalami kecemasan } \\
\text { ringan sebanyak } 10,7 \% \text {, orangtua yang } \\
\text { mengalami kecemasan sedang sebanyak }\end{array}$} \\
\hline
\end{tabular}


$78,6 \%$, dan orangtua yang mengalami kecemasan berat sebanyak $10,7 \%$. Setelah uji chi-square dapat dilihat bahwa nilai $p$ value $=0,034$ menunjukan bahwa ada hubungan yang signifikan antara hubungan caring perawat dengan kecemasan orangtua yang anaknya hospitalisasi.

\section{PEMBAHASAN}

\section{Caring perawat}

Hasil penelitian menunjukan bahwa hasil ukur caring perawat responden dengan menggunakan kuesioner, mayoritas responden menjawab caring perawat baik 51,9\%. Hal ini terbukti dari jawaban kuesioner responden yang menyatakan perawat menganjurkan saya bertanya tentang penyakit anak saya $46,4 \%$, perawat memperhatikan kenyamanan dan keamanan lingkungan seperti kebersihan 44,6\%, perawat menjelaskan tentang kondisi penyakit anak saya dan tindakan yang akan dilakukan $42,9 \%$, perawat memberi penjelasan dengan bahasa yang dimengerti $39,3 \%$

Caring merupakan sentral untuk praktik keperawatan karena caring merupakan suatu cara pendekatan yang dinamis, dimana perawat bekerja untuk lebih meningkatkan kepeduliannya kepada klien (Sartika \& Nanda, 2011). Dalam keperawatan, caring merupakan bagian inti yang penting terutama dalam praktik keperawatan. Caring juga digambarkan sebagai moral ideal keperawatan hal tersebut meliputi keinginan untuk merawat, kesungguhan untuk merawat, dan tindakan merawat (caring). Perawat mempunyai persepsi bahwa bila waktu mereka lebih banyak digunakan untuk berkomunikasi atau kontak dengan pasien, maka status mereka lebih rendah (Maulidia et al, 2016).
Penelitian Wicaksono, (2012) bahwa keperawatan yang baik dan sesuai harapan dalam sebuahrumah sakit meningkatkan mutu asuhan keperawatan dengan penerapan kiat caring perawat dan melakukan supervisi secara berkala sesuai standar untuk mengevaluasi kinerja perawat. Model asuhan keperawatan profesional yang lebih efisien dan efektif sehingga mampu memberikan kepuasan baik dari pihak pasien, keluarga, perawat maupun tim kesehatan lain.

Hal ini sejalan dengan penelitian Saraswati (2013) Hubungan caring perawat dengan kecemasan anak usia prasekolah akibat hospitalisasi di Ruang Melati RSUD kebumen. Hasil statistic uji korelasi antara kecemasan anak usia prasekolah dan caring perawat diperoleh -0.465 dengan nilai probabilitas (signifikan) sebesar 0.0007 dengan nilai signifikan $(a)$ sebesar 0.05

Hal ini juga sejalan dengan penelitian Abdul (2013) menunjukan bahwa 11,3\% responden mempunyai persepsi bahwa perawat pempunyai perilaku caring baik dan menunjukan kepuasan terhadap pelayanan keperawatan. Hasil uji futher menunjukan $p=0,000$, berarti terdapat hubungan yang signifikan antara perilaku caring perawat dengan tingkat kepuasan pasien diruang rawat inap rumah sakit umum daerah kota Baubau, namun masi terdapat $6,2 \%$ yang kurang puas dengan caring perawatnya. Menurut pendapat peneliti berdasarkan hasil penelitian caring perawat pelaksanaan sudah baik, tetapi masi terdapat sebagian perawat yang belum penerapkan senyum,sapa, sentuh kepada anak yang menjalani hospitalisasi sehingga dapat berpenggaruh terhadap proses pelayanan keperawatan. 


\section{Kecemasan orangtua yang anaknya hospitalisasi}

Hasil penelitian menunjukan bahwa kecemasan orangtua responden dengan mengunakan kuesioner responden menjawab mayoritas cemas sedang $61,1 \%$. Hal ini sesuai dengan jawaban responden yang diisi menunjukan bahwa membayangkan kondisi yang lebih buruk $81,5 \%$, sedih $72,2 \%$, perasaan gelisa $66,7 \%$, tidur tidak pulas $63,0 \%$ dan bingung $57,4 \%$

Hasil penelitian Efendi (2011) meneliti tingkat kecemasan orangtua saat anaknya dirawat inap (hospitalisasi) di Rumah Sakit Umum Daerah Dr. Soeroto Ngawi. Hasil penelitian menunjukan bahwa secara umum orangtua mengalami cemas berat $(37 \%)$, cemas ringan $(50 \%)$, dan sisanya tidak cemas. Orangtua yang anaknya hospitalisasi sebagian besar akan cemas. Tingkatan kecemasan orangtua berbeda-beda dikarenakan banyak factor yang mempengaruhinya.

Hal ini sejalan dengan penelitian Elfira (2011), yang menunjukan bahwa sebanyak $92,3 \%$ responden mengalami kecemasan sedang dan 7,7\% mengalami kecemasan berat. Setelah dilaksanakan terapi bermain dengan tehnik bercerita $76,9 \%$ responden mengalami kecemasan ringan dan $23,1 \%$ mengalami kecemasan sedang. Penelitian ini menunjukan bahwa terapi bermain dengan tehnik bercerita mempunyai pengaruh yang signifikan dalam penurunkan kecemasan anak dan orangtua $p=0,001 ; a=0,05$. Menurut pendapat peneliti kecemasan orangtua pada penelitian ini masi ada orangtua merasa cemas saat anaknya menjalani hospitalisasi. Hal ini akan berpengaruh pada kesembuhan anak karena peran orangtua dalam proses kesembuhan anak sangat diutamakan.

\section{Hubungan caring perawat dengan kecemasan orangtua yang anaknya hospitalisasi}

Hasil penelitian menujunkkan caring perawat buruk sebanyak $48,1 \%$ dengan orangtua yang mengalami kecemasan ringan sebanyak $38,5 \%$, orangtua yang mengalami kecemasan sedang sebanyak $46,2 \%$, dan orangtua yang mengalami kecemasan berat sebanyak 15,4\% . Responden yang menyatakan caring perawat baik sebanyak $51,4 \%$ dengan orangtua yang mengalami kecemasan ringan sebanyak $10,7 \%$, orangtua yang mengalami kecemasan sedang sebanyak $78,6 \%$, dan orangtua yang mengalami kecemasan berat sebanyak $10,7 \%$

Hasil uji chi-square dapat dilihat bahwa nilai $p$ value $=0,034$ menunjukan bahwa ada hubungan yang signifikan antara hubungan caring perawat dengan kecemasan orangtua yang anaknya hospitalisasi di ruang rawat inap delima lantai iv rsu sari mutiara medan tahun 2017. Hasil penelitian menunjukan bahwa caring perawat baik sebanyak $51,9 \%$ mengalami kecemasan sedang $78,6 \%$ dibandingkan caring perawat buruk sebanyak $48,1 \%$ mengalami kecemasan sedang 46,2\%, hasil penelitian ini menunjukan bahwa caring perawat baik mengalami kecemasan sedang dibandingkan dengan caring perawat buruk juga mengalami kecemasan sedang.

Perilaku caring perawat pelaksana di rumah sakit dapat dipengaruhi oleh budaya organisasi. Kreitner \& Kinicki (2010), menekankan bahwa budaya organisasi yang kuat menciptakan kesamaan tujuan, motivasi karyawan, dan struktur pengendalian untuk membentuk perilaku yang dibutuhkan dalam meningkatkan prestasi organisasi yang berdampak pada kinerja anggota organisasi. Bukti empirik mengenai 
faktor yang mempengaruhi perilaku caring perawat sebagai wujud kinerja. Menurut pendapat peneliti tentang hubungan caring perawat dengan kecemasan orangtua yang anaknya hospitalisasi di ruang rawat inap delima lantai IV RSU Sari Mutiara Medan 2017 didapatkan pelaksanaan caring perawat baik dan dapat ditingkatkan lagi. Caring perawat baik dikarenakan perilaku seseorang yang dipengaruhi pengetahuan, belajar dari pengalaman, kesabaran, kejujuran, rendah hati dan keberanian. Hal ini juga dapat meningkatkan pelayanan kesehatan dan kualitas rumah sakit itu sendiri.

\section{SIMPULAN}

Caring perawat mayoritas baik, Kecemasan orang yang anaknya hospitalisasi mayoritas sedang dan ada hubungan yang signifikan antara hubungan caring perawat dengan kecemasan orangtua yang anaknya hospitalisasi dengan nilai $p$ value $=$ 0,034 .

\section{DAFTAR PUSTAKA}

Abdul, A (2013). Hubungan prilaku caring perawat dengan tingkat kepuasan pasien rawat inap $R S U D$ Kota Baubau. Jurnal Keperawatan Universitas Hasanuddin.

Akhriansyah, M. (2018). Hubungan Pelaksanaan Komunikasi Terapeutik Dengan Tingkat Kecemasan Akibat Hospitalisasi Pada Anak Usia Sekolah Yang Dirawat Di Rsud Kayuagung Tahun 2017. Jurnal Ilmiah Universitas Batanghari Jambi, 18(1), 71-76. Doi:http://dx.doi.org/10.33087/jiub j.v18i1.434

Apriliawati, A (2011). Pengaruh Biblioterapi Terhadap Tingkat
Kecemasan Anak Sekolah Yang Menjalani Hospitalisasi Dirumah Sakit Islam Jakarta. Thesis. Depok : Universitas Indonesia.

De Breving, R. M., Ismanto, A. Y., \& Onibala, F. (2015). Pengaruh Penerapan Atraumatic Care Terhadap Respon Kecemasan Anak Yang Mengalami Hospitalisasi Di RSU Pancaran Kasih Gmim Manado Dan RSUP Prof. Dr. RD Kandou Manado. Jurnal Keperawatan, 3(2).

Efendi (2011) Tingkat Kecemasan Orangtua Saat Anaknya Dirawat di RSUD Dr. Soeroto Ngawi. Skripsi Universitas Muhammadiah Malang

Elfira, E. (2011). Pengaruh Terapi Bermain dengan teknik bercerita terhadap kecemasan akibat hospitalisasi pada anak usia prasekolah di ruang perawatan RSUP H Adam Malik Medan.

Gaghiwa L, Ismanto, Y, A dan babakal. A (2013). Hubungan perilaku caring perawat dengan stress hospitalisasi pada anak usia toddler. Di irina E Blue RSUD. Prof. Dr. R. D. kandau jurnal kesehatan. manado

Kreitner, R \& Kinikki (2010). Organizational Behavior. Neu York: Mc Graiw. Hill Higner education.

Kumayah, L. (2011). Kecemasan Orangtua Tentang Hospitalisasi Pada Anak (Studi di Paviliun Seruni RSUD Jombang). Jurnal Keperawatan, 1(1).

Lumiu, S.E. (2013). Hubungan dukungan keluarga dengan tingkat kecemasan akibat hospitalisasi 
pada anak di usia pra sekolah di irina E Blue RSUD Prop. Dr. R. D. kandau manado, jurnal keperawatan.

Maulidia ,R, Ugrasena G, \& Sufyanti, Y (2016), Penurun kecemasan dan koping orangtua dalam merawat anak yang mengalami hospitalisasi memaluipenerapan caring swansan di RS mardi waluyo blitar. Jurnal Hesti Wira Sakti . Surabaya.

Meliana, E. (2013). Hubungan Caring Perawat Dengan Tingkat Kecemasan Orangtua Terkait Hospitalisasi Anak Di Ruang Rawat Inap RSU Kota Bekasi 2013. Bekasi : Puplikasi Online Jurnal Keperawatan. Diakses Pada 2014.

Mulyatiningsih, E. (2014). Pengaruh Orientasi Terhadap Tingkat Kecemasan Anak Pra Sekolah Di Bangsal Anak Rumah Sakit Bhakti Wira Tamtama Semarang. FIKkeS, 7(1). Vol 7 No 1. 66-76.

Prabowo, B. S., Ardiana, A., \& Wijaya, D. (2014). Hubungan Tingkat Kognitif Perawat tentang Caring dengan Aplikasi Praktek Caring di Ruang Rawat Inap RSU dr. H. Koesnadi Bondowoso (The Correlation between Nurses Cognitive Level on Caring with Caring Practice Application in the Inpatient Unit RSU dr. H. K. Pustaka Kesehatan, 2(1), 148-153.

Purwandari, H. (2009). Pengaruh terapi seni dalam menurunkan tingkat kecemasan anak usia sekolah yang menjalani hospitalisasi di wilayah Kabupaten Banyumas $=$ The effect of art therapy to reduce anxiety level on school age children
Undergoing Hospitalization in Banyumas District.

Saraswati, (2013). Hubungan Caring Perawat Dengan Kecemasan Pada Anak Usia Prasekolah Akibat Hospitalisasi Di Ruang Rawat Inap Melati RSUD Kebumen. Skripsi Sekolah Tinggi Ilmu Kesehatan Muhamadiyah Gombong.

Sarifah M, Arbianingsih, dan Huriati (2016). Pengaruh senan otak terhadap kecemasan pada anak usia sekolah yang mengalami hospitalisasi. Jurnal of Ialamic Nursing : Makassar.

Sartika \& Nanda (2011). Konsep Caring. Dari http://www.pedoman.news.com.

Setiawan, D. (2014). Keperawatan Anak dan Tumbuh Kembang. Yogyakarta: Nuha Medika.

Suryanti, M. (2013). Pengaruh terapi bermain puzzle terhadap dampak hospitalisasi pada anak usia pra sekolah di ruangan anggrek 1 rumah sakit polpus RS Sukanto Jakarta : kakulasi kedokteran UPN Veteran Jakarta.

Wartawan, I. W (2012). Analisis Lama Hari Rawat Pasien Yang Menjalani Pembedahan Di Ruang Rawat Inap Bedah Kelas III RSUP Sanglah Denpasar Tahun 2011.

Wicaksono, et,al (2012). Kiat Keperawatan (Caring) Dalam Peningkatan Asuhan Keperawatan : Puplikasi Online Jurnal Kesehatan STIKES RS Baptis Kediri. 